\title{
Native Culture and Gender Politics in Nagaland: A Study of Easterine Iralu a Terrible Matriarchy
}

\author{
Veena Gour \\ Research Scholar \\ Barkatullah University \\ Bhopal, Madhya Pradesh, India \\ veena.gour@rediffmail.com
}

\begin{abstract}
The paper aims at examining Easterine Kire Iralu's novel A Terrible Matriarchy (2007) from feminist point of view. The novel A Terrible Matriarchy is the coming-of-age story of a young girl, Dielieno. The narrative explores the suffering of innocent Dielieno and her confrontation with the traditional Angami society to which she belongs to. In the ethnic world of Nagaland, both patriarchal and matriarchal control co-exists but it also has a strong Tantric tradition from time immemorial. For various reasons the status of women in the northeast has not been different from the women in the mainstream of India. Easterine Iralu through her girl protagonist Dielieno depicts the severe gender discrimination where the grandmother neglected Lieno to the worst extent, always caring and preferring the boys. The
\end{abstract}


grandmother's matriarchal hegemony makes Lieno revolt silently. The various aspects of women's marginal status and native culture have been analyzed in the paper.

Keywords: Matriarchal Hegemony, Gender Politics, Native Culture.

Easterine Kire Iralu is an English novelist from North-East Indian state Nagaland. She writes about certain specific concern of society and women issue in her own manner. Her fiction with rare insight and finesse bonds author's relation with her work. Her writing reflects native culture, traditions, conflicts and compromises, resolutions and irresolution, ironies and affirmations, triumphs and tragedies through ongoing process of life in that region. This way of looking at human condition concretises major theme of her fiction as cultural depiction, woman- woman relationship, gender discrimination, marginalisation, rebellion and protest.

Her novel A Terrible Matriarchy (ATM) is an evocative tale of young five years old girl Dielieno growing up in a traditional Naga society in India's North-East. The setting of the novel is Nagaland, a state in North-Eastern India during 1970's or 1980's. The novel revolves round its tiny protagonist Dielieno and describes her journey from a little child to a young woman who finally got married in the end. The story is greatly inspired by writer's own life and characters are mostly based on real people. The story portrays patriarchal set up of the Naga society.

Dielieno was the youngest in five children family and was the only girl child. Though darling of her parents she felt unwanted and thinks that she was an afterthought since her parents often made her wear left over clothing of her elder brothers. At the age of five, she was sent to live with her disciplinarian grandmother Vibano who wanted her to grow up to be good Naga wife and mother. The narrative of the novel is in first person through the innocent eyes of Dielieno. 'Dielieno' the Angami name actually mean errand girl, so it is the name that tells us status of girl child in Angami society and describes much of her life from five to 
twenty three years. In traditional Naga society, a girl child is considered good for running errands and looking after household chores.

But this novel is not just about Dielieno's story. It was about three generation of Naga women: grandmother, mother and Dielieno. Thus by depicting lives of women of three generations showcased the time of rapid social change. There are different layers to the novel. In the first level, it is Dielieno story that fights against terrifying odds to get education and place in society.

"I was youngest in my family of five children, I sometimes felt I was an afterthought and may be Father and Mother didn't quite know what to do with me. Also because I was a girl after four boys, they never seemed to be sure whether to buy me girls clothing or let me wear leftover boys clothing.” (ATM, Pg-2)

She was a strong and sensitive woman who had not lost her spirit against all odds in her early life. Easterine asserts that Dielieno is not a feminist character but a womanist. She was intelligent and curious girl who struggle against her grandmother's effort to tame her or indeed, can say wants to break her spirit. Throughout the novel the tension is evident between grandmother and granddaughter. "My grandmother didn't like me. I knew this when I was about four and a half." (ATM Pg- 1). The writer has realistically portrayed gender discrimination in a casteless society.

In a review Kezhakielie Whiso (Eastern Mirror, Gujarat) expressed that the book fascinates the reader by its "storytelling within the story". The visible structure of the novel is patriarchal but in the backdrop it describes matriarchy as an under- structure misusing the patriarchal system. And it abuses the patriarchal system resulting in gender abuse with the same gender. This was witnessed in many women - women relationships of the novel for e.g. Grandmother - Dielieno relationship, Grandmother -Bano relationship and Bano- Seno / Leno relationship. The subtle but principal theme of the novel is about being a woman in a 
society runs by customary laws that provides only token gestures to the rights and desires of a woman. This was the prime cause of conflict between Dielieno and her Grandmother. The non -status of woman is seen repeatedly in the novel. Daughters cannot inherit ancestral property. Women have no voice or little voice in such matters.

Grandmother's obsession with male heirs and her sexist views make Dielieno hate her with a vengeance. While Grandmother dotes on her grandsons, she detests female freedom in any form. She is the matriarch who binds her family in strict rules; she is the abuser of the patriarchal power resulting in gender abuse within the same gender, and in the process she ends up abusing herself. Apart from Dielieno there are other female characters in the novel who suffer under the patriarchal structure of the Angami society of Nagaland. Neikuo, Bano, Nisano - the lives of these women are testaments to the presence and prevalence of patriarchy in the Naga social fabric. Neikuo, the old unmarried sister of Sizo and Grandmother Vibano, has no property of her own.

As it is a males-only heir system in Nagaland, Neikuo inherits nothing from her paternal wealth; and remaining a spinster has only multiplied her woes. She is living at the mercy of her brother Sizo who has allowed her to live in his paternal house, as he is living elsewhere with his family. Dielieno loves grandmother Neikuo for her understanding and helpful nature and wonders how two biological sisters can be so different. Then comes Bano, Sizo's illegitimate daughter who has no social recognition and lives with her aunt Vibano. She calls Vibano 'Mother' as she has never met her own biological mother. Bano toils from dawn to dusk, running errands for Vibano who has no sympathy for girls. When she grows up to be a beautiful young woman, marriage proposals start coming in, but Vibano keeps on rejecting the proposals saying that Bano deserves better. But soon we figure out the selfish motive; Vibano wants to keep Bano with her as she is of great help in her old age. Bano dedicates her life in looking after Vibano, and in return gets nothing. Though Vibano wanted 
Bano to live in her house even after her death, Bano is turned out of the house immediately after Vibano's death ; Vibano's sons inherit the house and they plan to use the house for some other purposes. Even the last wish of the matriarch is not valued in the world of patriarchy, the fabric of which has always been strengthened by the matriarch herself throughout her life. Here the abuser gets abused in the power-play of gender politics.

Though A Terrible Matriarchy is set in the second half of twentieth century, we get the glimpse of 40s when the Battle of Kohima was faught. Dielieno's mother was a young girl then; the Japanese soldiers were taking over the southern villages of Nagaland. More and more British soldiers were sent to Kohima to tackle them. One day a British officer got inside the house of Dielieno's mother and tried to molest her - "Suddenly the Officer pulled her into his arms and there was no doubt what his intention was."(A Terrible Matriarchy, 171) She was saved somehow and later on it was proved that the soldier was a German spy masquerading as a British Officer. But many women were not as lucky as her; they were tortured and ravaged during the wartime as they had to leave their houses behind to save themselves from gunfire and bombings.

Back to the second half of the twentieth century, the situation is no different. During 1940s the Naga people suffered in the hands of foreign armed forces, and in the 70s and 80s they had to deal with the Indian armed forces as well as some homegrown factional groups and military oppression. Apparently an area of male concern, the Indo-Naga conflict has reinforced the non-status of women in society. Such unresolved political conflicts put the Naga women in double crisis - they had to suffer in the hands of their male counterparts, and had to bear the brunt of the armed forces as well.

Identity crisis, alienation, unemployment, insecurity and the political suppression of Naga rights led the frustrated Naga youths to the drinking houses which spawned in every nook and corner of Nagaland. These houses used to serve adulterated alcohol that caused 
many pre-mature deaths, but there was no escape from this. Naga youths took refuge in alcohol which, they thought, would save them from their social and economic impotence. When the male members returned home from the drinking houses, they indulged themselves in wife-battering which was thought to be manly and emotionally cathartic as well. Ironically, when they died of alcoholism, the womenfolk of the family had to suffer the most. Nisano was at the mercy of Grandmother Vibano after the death of Vini who bled to death due to extreme alcoholism. Even when she was staying with her in-laws she found it tough to tackle the gossipmongers who were not ready to accept a widow living with her in-laws even after her husband's death.

In the story we find that the protagonist, who is a five year old girl at the beginning, grows up to be an intelligent young woman with a womanist point of view who has the ability to fathom the causes and reasons behind the apparent reality. Her hatred for her grandmother gets minimised when she learns the reason behind her sexist behaviour. Her mother helps her to understand her grandmother when she explains-

"When she was young she lived through a very hard age. In the village, widows without sons lost all their husband's property to other male relatives. . . Grandmother saw her own mother suffer hardship and poverty and exclusion from many aspects of social life because she had no brothers. It hardened her and made her determined not to suffer as her mother had."(ATM, 250)

The above lines reveal the reasons behind Grandmother's preference for boys. She looks at her sons and grandsons as a kind of insurance and so doted on them dearly. Dielieno realises - "After my talk with Mother, I understood better the deep sense of insecurity that had led Grandmother to hold the world view she had." (ATM, 253)

She was a matriarch with a sense of lack and insecurity - insecurity caused by the lack of agency, insecurity caused by the lack of security and insecurity caused by the lack of 
power. And the causes for these insecurities are socio-economic in nature. Uneven balance of wealth and lack of agency have led to the subjugation of women in general. But women from the post-colonial milieus are the worst sufferers. The roots of all these lie in colonialism and its long lasting effects in the post-colonial setting.

However, we find that the change is not far away; in fact it is the time for rapid social change. Mother was adamant to send Dielieno to school and make her finish her education as she herself was a failure in this respect. Dielieno gets her education and comes out with flying colours. Though Mother was weak and lacked agency, but nonetheless she was the whistleblower. Her words of comfort and inspiration made Dielieno a courageous woman with a sense of humanity and social justice:

"You know that our people say we should love our sons because they are the ones who look after us in our old age. .. but for your father and I , it is you, our daughter, who has brought us the greatest comfort. We love all of you equally. You must always know that.” (A Terrible Matriarchy, 250)

The change reached out to Grandmother too, but it was too late. In her deathbed she could realise how cruel she had been towards her granddaughter; silent tears ran down her cheeks. The story ends with a hope. At the end of the book, we find that peace was restored in the lives of the remaining characters, but not before the ghost of the matriarch got appeased. The matriarch who unwittingly became the upholder of patriarchy was herself its victim, and when this realisation dawned upon her it was already too late. It seems that her sense of lack overpowered her entire being. At the end of the novel Grandmother's crazed self reappears as the ghost.

Even after her death Grandmother started haunting the paying guests of her house until the house was inhabited by its rightful owners - Bano and, Vini's wife and son. Thus, we may conclude that A Terrible Matriarchy is a coming-of-age story of a girl as well as of 
her Grandmother in the Angami society of Nagaland which has faced many socio-political struggles that have continuously strengthened the matrix of patriarchy in the fabric of Naga society. 


\section{References}

Kire, Easterine. A Terrible Matriarchy. New Delhi: Zubaan, 2007. Print.

Kire, Easterine. Bitter Wormwood. New Delhi: Zubaan, 2011. Print. Postcolonial feminism.Wikipedia.nd.Web.28 May, 2015. //< en.wikipedia.org/wiki/Postcolonial feminism >

Theory and Society Vol. 19, Netherlands: Kluwer Academic Publishers, 1990. Print 